\title{
Improving Interpersonal Intelligence Through Hompimpa Games in Children at 4 - 5 Years Old at Annida Ya Fatimah Kindergarten Tayu Pati
}

\section{Luluk Elyana, Soraya Rosna Samta}

Prodi Pendidikan Guru Pendidikan Anak Usia Dini, Fakultas Keguruan dan Ilmu Pendidikan, Universitas IVET, Indonesia

\section{Info Articles}

Sejarah Artikel:

Disubmit 4 Juli 2021

Direvisi 6 Juli 2021

Disetujui 31 Juli 2021

\section{Keywords:}

Hom Pim Pa Game,

Interpersonal Intelligence

\begin{abstract}
Abstrak
Tujuan penelitian ini mendiskripsikan peningkatan kecerdasan interpersonal anak melalui permainan hom pim pa di TK Annida Ya Fatimah Tayu Pati. Adapunpendekatan yang diterapkandalampenelitianiniadalahpendekatan kualitatif, dengan metode deskriptif, hal ini disesuaikan dengan tujuan pokok penelitian yang ingin dicapai yaitu untuk mediskripsikan dan menganalisa peningkatan kecerdasan interpersonal anak melalui permainan hom pim pa. Subyek penelitian adalah seluruh peserta didik TK Annida Ya Fatimah Tayu Pati dengan jumlah 18 anak, yang terdiri dari 8 anak perempuan dan 11 anak laki-laki. Dari hasil penelitian dapat disimpulkan bahwa pembelajaran dengan permainan hom pim pa dapat meningkatkan kecerdasan interpersonal anak $89 \%$, peningkatan ini melampaui standar keberhasilan yang ditetapkan yaitu $80 \%$. Peningkatan keberhasilan kecerdasan interpersonal anak tersebut didasarkan pada hasil penelitian siklus I dan siklus II dengan indicator capaian peserta didik (1) sikap mampu bekerjasama dengan teman (2) sikap mampu berinteraksi dalam bermain (3) sikap mampu beradaptasi dengan teman berbeda kelompok (4) sikap mampu menyelesaikan pekerjaan bersama teman-temannya.
\end{abstract}

\section{Abstract}

The purpose of this study is to describe the improvement of children's interpersonal intelligence through hom pim pa games at Annida Ya Fatimah Kindergarten Tayu Pati Kindergarten.The approach applied in this study is qualitative approach, with descriptive method, this is in accordance with the main purpose of the research to be achieved, namely to describe and analyze the improvement of children's interpersonal intelligence through hom pim pa game. The subjects of the study were all students of Annida Ya Fatimah Kindergarten Tayu Pati with a total of 18 children, consisting of 8 girls and 11 boys. From the results of the study, it can be concluded that learning with hom pim pa game can improve children's interpersonal intelligence by $89 \%$, this increase exceeds the standard of success set at $80 \%$. The improvement of the child's interpersonal intelligence success is based on the results of the study of cycle I and cycle II with indicators of student achievement (1) the attitude of being able to cooperate with friends (2) the attitude of being able to interact in playing (3) the attitude of being able to adapt to different group friends (4) the attitude of being able to finish work with friends

\footnotetext{
Alamat Korespondensi:

E-mail: alamat@email.mu
}

p-ISSN XXXX-XXX e-ISSN XXXX-XXX 


\section{PENDAHULUAN}

Usia dini merupakan masa emas perkembangan. Pada masa itu terjadi lonjakan luar biasa pada perkembangan anak yang tidak akan terjadi pada periode berikutnya. Para ahli menyebutnya sebagai usia emas perkembangan (golden age). Untuk melejitkan potensi perkembangan tersebut, setiap anak membutuhkan penanganan yang tepat sesuai dengan tahap perkembangannya.Pendidikan pada Taman Kanak - Kanak merupakan salah satu bentuk pendidikan anak usia dini yang memiliki peranan sangat penting (Elyana, 2018). Pendidikan untuk anak usia dini khususnya Taman Kanak - Kanak perlu menyediakan berbagai kegiatan yang dapat mengembangkan berbagai aspek perkembangan anak.

Menurut Maria Montessori, Anak Usia Dini berada pada masa peka. Masa peka merupakan suatu masa yang ditandai dengan pesatnya perkembangan suatu fungsi jiwa yang dimiliki oleh anak, seperti kemampuan fisik motorik, bahasa dan sosial emosi. Salah satu potensi perkembangan anak adalah peningkatan kemampuan sosial emosional yang memiliki dimensi perkembangan anak mampu mengelola emosi dengan baik, beradaptasi dengan lingkungan dan teman sebaya serta memiliki sikap sosial menurut tahapan usianya. Pendidik berperan sebagai fasilitator, mediator dan komunikator bagi anak. (Elyana,2020)

Program pemerintah kota layak anak satu desa satu PAUD mengharuskan setiap desa minimal memiliki satu PAUD. Hal tersebut perlu diimbangi dengan kualitas kesiapan pendidik dan penyamaan persepsi dengan para orang tua bahwa anak harus mendapatkan pemenuhan haknya bermain dan berinteraksi dengan teman - temannya. Pemahaman orang tua adalah anak hanya mendapatkan prioritas membaca, menulis dan berhitung sebagai kesiapan masuk ke jenjang pendidikan berikutnya. Kondisi demikian juga terjadi di Taman Kanak - Kanak Annida ya Fatimah Jepat Lor Tayu Pati, dimana kondisi masyarakat dengan pola pikir konvensional yaitu anak - anak lebih penting belajar calistung atau baca, tulis dan berhitung. Potensi kemampuan anak penting untuk di stimulasi tumbuh kembangnya salah satunya peningkatan kecerdasan interpersonal.

Konsep kecerdasan yang mengalami perdebatan panjang membuat seorang ahli psikologi dari Harvard University Howard Gardner mengadakan penelitian dengan hasil penelitian yang di kenal dengan multiple intelligences (MI) atau kecerdasan jamak. Anak pada usia ini merupakan individu yang mengalami pertumbuhan yang pesat. Pada fase ini disebut sebagai masa usia emas karena anak-anak dapat memperluas semua aspek perkembangannya di usia ini (Papalia \& Feldman, 2014). Setiap anak memiliki karakteristik yang berbeda-beda (agama, moral, fisik motoric, kognitif, Bahasa, social emosional, dan seni) yang seimbang dan dikembangkan secara optimal Lev Vygotsky (Bewer, 2007). Keterampilan kecerdasan interpersonal pada anak yang berusia 4-6 tahun anak belajar untuk tahu lebih banyak tentang kehidupannya (Jamaris dan Edwita, 2014).

Kecerdasan interpersonal merupakan kemampuan dalam memahami serta memperkirakan perasaan, suasana hati, serta keinginan orang lain di sekitar anda dan dapat merespon nya dengan layak (Lwin, 2005). Individu mampu memahami serta membedakan suasana hati, motivasi, kehendak serta perasaan orang lain di sekitarnya. Memiliki intuisi yang peka terhadap berbagai ekspresi wajah, gerakan tubuh, serta suara orang lain bahkan mampu memberikan respon positif yang efektif dalam berkomunikasi Safaria (2005) menjelaskan bahwa Kecerdasan interpersonal adalah kemampuan serta ketrampilan seseorang untuk menciptakan hubungan sosial sehingga kedua belah pihak yang berada didalam situasi benar-benar saling menguntungkan satu sama lainnya. Terdapat 3 (tiga) tingkat dimendi kecerdasan interpersonal yaitu:

1. Social Sensitivity

Social sensitivity atau yang dikenal dengan senstivitas sosial, merupakan kemampuan seseorang dalam merasakan dan mengamati berbagai macam reaksi pada individu yang kemudian 
ditunjukkan baik dalam bentuk verbal ataupun non verbal. Sensitivitas sosial ini memiliki indikator sikap empati dan sikap prososial.

2. Social Insight

Merupakan kemampuan dalam memahami serta mencari solusi dari permasalahan yang efektif di dalam interaksi sosial. Sehingga masalah-masalah yang ada tidak akan menghambat hubungan sosial yang sudah terbentuk sebelumnya. Pondasi dasar dalam sosial insight adalah berkembanganya kesadaran individu secara baik. Beberapa indikator di dalam sosial insight, yaitu kesadaran diri, terampil dalam pemecahan masalah, paham situasi sosial atau etika sosial.

3. Social Communication

Kemampuan seseorang dalam berkomunikasi baik dalam bentuk komunikasi verbal maupun non verbal. Kemampuan berkomunikasi ini mencakup dalam ketrampilan berbicara, menulis, public speaking, hingga mendengarkan dengan efektif.

Perlu disertakan media pembelajaran berupa permainan tradisional yang menimbulkan suasana gembira pada anak saat pembelajaran dengan tujuan anak merasa nyaman dan lepas dari tekanan orang tua. Media pembelajaran yang dipilih adalah dalam bentuk permainan tradisional Hom Pim Pa. Melalui permainan tersebut anak dapat belajar untuk bersosialisasi, mengendalikan diri atau emosi, solidaritas, serta dapat menghargai orang lain (Seriati \& Hayati, 2010). Bemain merupakan salah satu cara anak mengekspresikan emosinya secara bebas (Emolu, 2014). Sejalan dengan pendapat Eberle (2011) menyatakan bahwa bermain dapat merangsang perkembangan mental, fisik, serta keterampilan sosial anak. Permainan Hom Pim Pa dapat membantu anak-anak dalam merangsang kecakapan hidup.

\section{METODE}

Peneliti melaksanakan penelitian dengan menggunakan metode kualitatif, yaitu metode penelitian naturalistik karena penelitian dilakukan pada kondisi yang alamiah (natural setting). Analisis data yang dilakukan bersifat induktif berdasarkan fakta-fakta yang dilakukan di lapangan dan kemudian dikonstruksikan menjadi teori. Penelitian dilakukan pada objek yang alamiah yaitu objek yang berkembang apa adanya. Dalam metode ini dimungkinkan dapat mempermudah peneliti dalam melakukan penelitian. Dilihat dari objeknya, jenis penelitian ini adalah ptk (classroom action research) yaitu penelitian praktis yang dimaksudkan untuk memperbaiki pembelajaran di kelas (pardjono, 2007:5). Subyek penelitian yang digunakan adalah anak usia 4 - 5 tahun di tk annida ya fatimah tayu pati. Instrumen penelitian menggunakan teknik trianggulasi yaitu wawancara, dokumentasi dan observasi terhadap subyek penelitian. Peneliti melakukan wawancara terhadap para guru terhadap keberhasilan pembelajaran kemampuan interpersonal anak. Terdapat beberapa catatan penting yang perlu dilakukan tindakan lebih lanjut yaitu dengan cara observasi untuk memperoleh data secara lengkap. Penelitian ini memerlukan kecermatan dan strategi dalam konsistensi terhadap fokus penelitian. Banyak permasalahan yang perlu dicarikan solusi dan penanganan yang muncul dalam proses pembelajaran.

\section{HASIL DAN PEMBAHASAN}

Pembahasan hasil penelitian disajikan berdasarkan temuan yang didapatkan dan disajikan dalam dua pokok bahasan:

1. Kecerdasan Interpersonal

Kecerdasan merupakan suatu kemampuan mental yang dibawa oleh individu sejak lahir untuk menyesuaikan diri dengan lingkungan yang baru dan memecahkan masalah-masalah secara tepat dan cepat. Menurut gardner (2003), kecerdasan adalah kemampuan menghasilkan persoalan 
baru untuk diselesaikan. Gardner juga mengemukakan bahwa kecerdasan seseorang berbeda-beda meliputi unsur-unsur yaitu kecerdasan metematik, kecerdasan bahasa, kecerdasan musikal, kecerdasan visual spasial, kecerdasan kinestetik, kecerdasan inter personal, kecerdasan intra personal dan kecerdasan naturalis. Sedangkan alfred binet seperti yang dikutip oleh musfiroh (2010:13) mengemukakan bahwa kecerdasan adalah kemampuan yang terdiri dari tiga komponen yaitu: 1. Kemampuan untuk mengasah pikiran atau tindakan 2. Kemampuan untuk mengubah arah pikiran atau tindakan 3. Kemampuan untuk mengkritisi pikiran dan tindakan dari diri sendiri.

Kecerdasan interpersonal merupakan kemampuan dalam memahami serta memperkirakan perasaan, suasana hati, serta keinginan orang lain di sekitar anda dan dapat merespon nya dengan layak (Lwin, 2005). Individu mampu memahami serta membedakan suasana hati, motivasi, kehendak serta perasaan orang lain di sekitarnya. Memiliki intuisi yang peka terhadap berbagai ekspresi wajah, gerakan tubuh, serta suara orang lain bahkan mampu memberikan respon positif yang efektif dalam berkomunikasi Safaria (2005) menjelaskan bahwa Kecerdasan interpersonal adalah kemampuan serta ketrampilan seseorang untuk menciptakan hubungan sosial sehingga kedua belah pihak yang berada didalam situasi benar-benar saling menguntungkan satu sama lainnya. Terdapat 3 (tiga) tingkat dimendi kecerdasan interpersonal yaitu

\begin{tabular}{|c|c|c|}
\hline \multicolumn{3}{|c|}{ KECERDASAN INTERPERSONAL } \\
\hline SOCIAL SENSITIVITY & SOCIAL INSIGHT & SOCIAL COMMUNICATION \\
\hline $\begin{array}{l}\text { Social sensitivity atau yang } \\
\text { dikenal dengan senstivitas } \\
\text { sosial, merupakan kemampuan } \\
\text { seseorang dalam merasakan } \\
\text { dan mengamati berbagai } \\
\text { macam reaksi pada individu } \\
\text { yang kemudian ditunjukkan } \\
\text { baik dalam bentuk verbal } \\
\text { ataupun non verbal. Sensitivitas } \\
\text { sosial ini memiliki indikator } \\
\text { sikap empati dan sikap } \\
\text { prososial }\end{array}$ & $\begin{array}{l}\text { Merupakan kemampuan dalam } \\
\text { memahami serta mencari solusi dari } \\
\text { permasalahan yang efektif di dalam } \\
\text { interaksi sosial. Sehingga masalah-masalah } \\
\text { yang ada tidak akan menghambat } \\
\text { hubungan sosial yang sudah terbentuk } \\
\text { sebelumnya. Pondasi dasar dalam sosial } \\
\text { insight adalah berkembanganya kesadaran } \\
\text { individu secara baik. Beberapa indikator di } \\
\text { dalam sosial insight, yaitu kesadaran diri, } \\
\text { terampil dalam pemecahan masalah, } \\
\text { paham situasi sosial atau etika sosial }\end{array}$ & 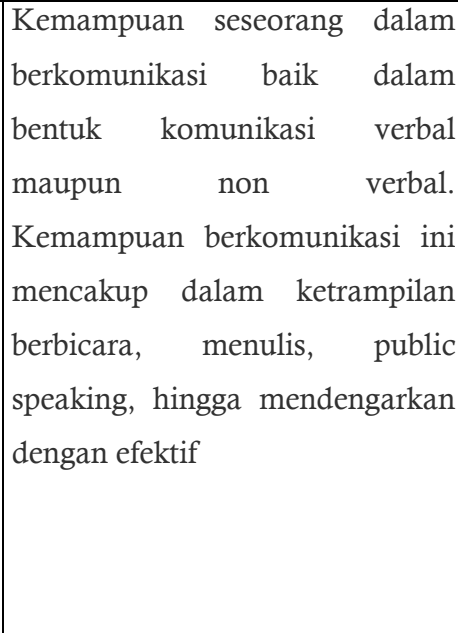 \\
\hline
\end{tabular}

\section{Permainan Hom Pim Pa}

Hompimpa atau hompimpah adalah sebuah cara untuk menentukan siapa yang menang dan kalah dengan menggunakan telapak tangan yang dilakukan oleh minimal tiga peserta. Biasanya hompimpa digunakan oleh anak-anak untuk menentukan giliran dalam sebuah permainan. Sewaktu bermain petak umpet misalnya, anak yang kalah hompimpa mendapat giliran sebagai penjaga pos. Tetapi aturan ini dapat berubah sesuai kesepakatan dari para pemain. Secara bersama-sama, peserta mengucapkan kata hom-pim-pa. Ketika mengucapkan suku kata terakhir ( $p a)$, masing-masing peserta memperlihatkan salah satu telapak tangan dengan bagian dalam telapak tangan menghadap ke bawah atau ke atas. Dalam budaya Jawa, hompimpa dilakukan dengan kalimat "Hompimpa alaium gambreng", sedangkan dalam budaya Betawi, hompimpa dilakukan dengan kalimat lebih panjang, yakni "Hompimpa alaium gambreng. Mpok Ipah pakai baju rombeng.

Para pemain melakukan hompimpa. Para pemain yang menghadap ke arah yang sama dengan jumlah sedikit akan keluar meninggalkan permainan, biasanya dianggap menang. Proses itu dilakukan berulang-ulang hingga hanya terdapat dua pemain. Biasanya, mereka melakukan suten 
(suit) untuk menentukan siapa yang keluar permainan Berdasarkan penelitian pada siklus I dan siklus II bahwa kecerdasan interpersonal anak dapat ditingkatkan melalui permainan Hompimpa pada anak usia 4 - 5 Tahun di TK Annida Ya Fatimah Tayu Pati.

Pada siklus I yang mendapatkan, nilai baik ada 10 anak atau mencapai $60 \%$, nilai cukup ada 6 anak atau mencapai $40 \%$ dan yang kurang 2 anak mencapai $10 \%$.

\begin{tabular}{|c|c|c|c|c|c|c|}
\hline \multirow{2}{*}{ Indikator } & \multicolumn{2}{|c|}{} & \multicolumn{2}{|c|}{$\sqrt{2}$} \\
\cline { 2 - 7 } & & & & & & \multicolumn{2}{c|}{} \\
& & & & & & \\
& & & & & & \\
\hline Pramlah Anak Prosentase \% & Jumlah Anak & Prosentase \% & Jumlah & Prosentase \% \\
\hline Siklus I & 10 & $50 \%$ & 6 & $40 \%$ & 2 & $10 \%$ \\
\hline Siklus II & 14 & $80 \%$ & 4 & $20 \%$ & 0 & $0 \%$ \\
\hline
\end{tabular}

Tabel 2.1 : Nilai Hasil Pembelajaran Pra Siklus, Siklus I, Siklus II

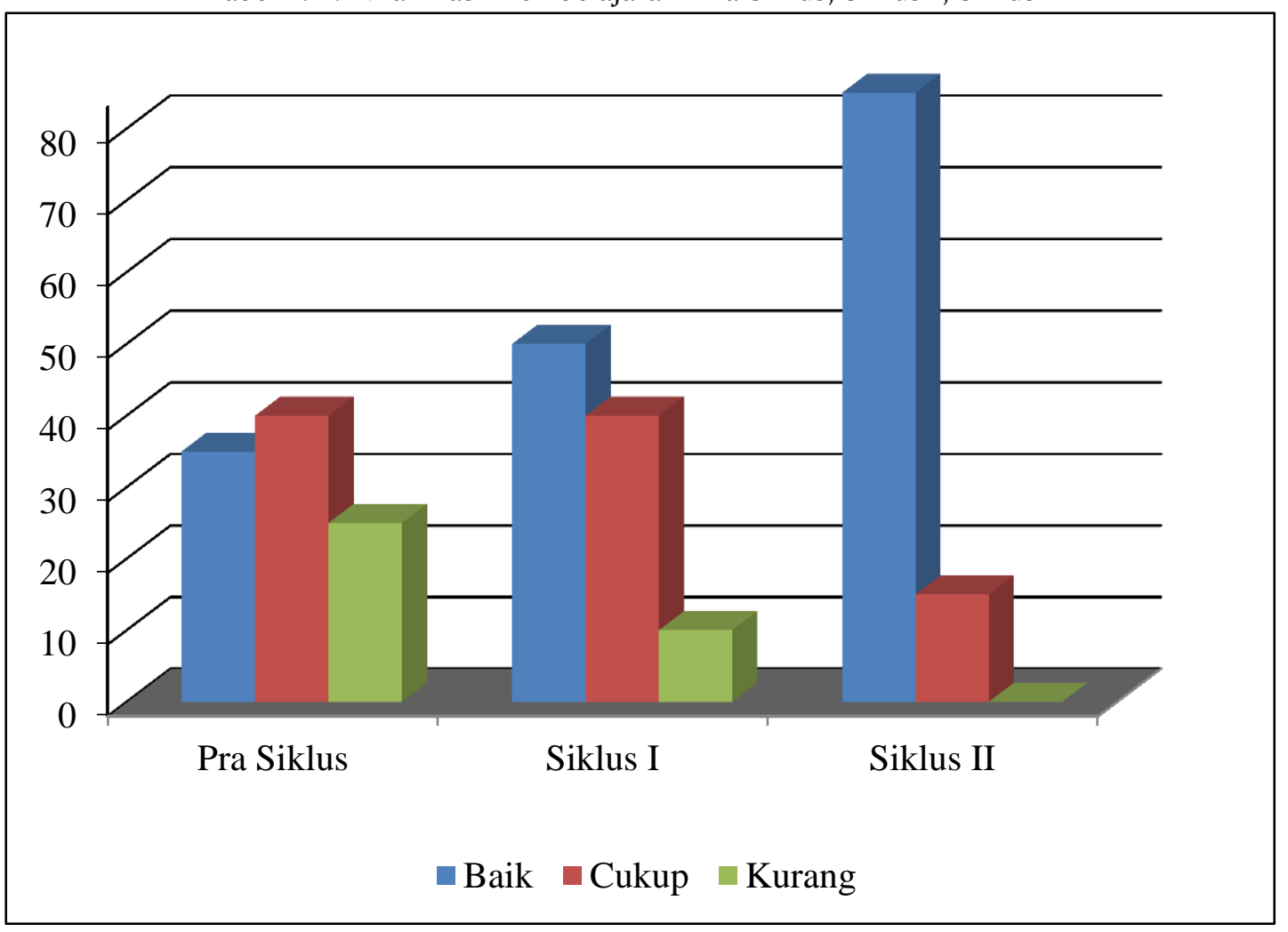

Gambar 2.1 Grafik Kondisi Antar Siklus 


\section{SIMPULAN}

Berdasarkan hasil tindakan siklus I, siklus II dan pembahasan hasil penelitian dapat disimpulkan bahwa, hipotesis tindakan yang berbunyi: "Improving Interpersonal Intelligence Through Hompimpa Games in Children at 4 - 5 Years Old at Annida Ya Fatimah Kindergarten Tayu Pati terbukti atau signifikan. Hal ini terbukti dari hasil tindakan Siklus I dan II. Hasil penelitian menunjukkan adanya peningkatan kemampuan kecerdasan interpersonal ke-18 anak subjek penelitian dari kondisi pra siklus $10 \%$ anak yang sudah mencapai baik. Siklus I kemampuan kecerdasan interpersonal ke-18 anak subjek penelitian menjadi $50 \%$ yang sudah baik mengenal angkanya. Setelah siklus II penguasaan anak terhadap kecerdasan interpersonal menjadi $80 \%$. Sehingga penelitian ini dianggap berhasil meningkatkan kemampuan kecerdasan interpersonal pada anak usia $4-5$ tahun.

\section{DAFTAR PUSTAKA}

Brewer, JA . 2007. Pengantarke awal pendidikan: Preschool melalui nilai utama . Amerika Serikat: Pearson.

Eberle, S. 2011. Bermain dengan kecerdasan ganda bagaimana permainan membantu mereka tumbuh. Jurnal amerika, 4(1), 19-51.

Elyana, L. 2020. Manajemen Parenting Class Melalui Media E-Learning. Sentra Cendekia, 1(1), 2935 .

Elyana, L., Utanto, Y., Widhanarto, G. P., \& Maretta, Y. A. 2018. Analysis of parent's discriminant partnership in the success of implementation of good school governance. In MATEC Web of Conferences (Vol. 205, p. 00012). EDP Sciences.

Emolu , E. 2014. Bermain, mainan dan sosialisasi gender . Jurnal Pendidikan Plus , 11(2), 22-30.

Gardner, Howard. 1993. Frames Of Mind: The Theory of Multiple Intelligence. New York: Basic Books

Jamaris , M. \& Edwita . 2014. Instrumen penilaian kecerdasan ganda formal untuk anak usia 4-6 tahun. Amerika Journal of Pendidikan Penelitian, 2 (12), 1167-1174.

May Lwin.et al. 2008. Cara Mengembangkan Berbagai Komponen Kecerdasan. Jakarta: PT INDEKS.

Musfiroh, Tadkiroatun. 2008. Cerdas Melalui Bermain. Jakarta: Grasindo

Papalia, DE \& Feldman, RD.2014. Menyelami perkembangan manusia (edisike12). Jakarta: Salemba Humanika

Safaria, T. 2005. Interpersonal Intelligence: Metode Pengembangan Kecerdasan Interpersonal Anak. Yogjakarta: Amara Books.

Seriati, NN \& Hayati, N. 2010. Permainan tradisional jawa gerak Dan lagu untuk review menstimulasi keterampilan sosial Anak Usia Dini 